\title{
EXPLORING THE UNIQUENESS OF POST SCHOOL TRANSITION PROGRAM FOR STUDENTS WITH DISABILITIES IN SPECIAL EDUCATION: A STUDY ON CURRICULUM DIVERSIFICATION IN INDONESIA
}

\author{
Gunarhadi $^{1 *}$, Munawir Yusuf ${ }^{1}$, Subagya $^{1}$, Mohd Hanafi bin Mohd Yasin ${ }^{2}$ and Mohd \\ Mokthar Bin Tahar ${ }^{2}$ \\ ${ }^{1}$ Sebelas Maret University, Indonesia \\ ${ }^{2}$ Universiti Kebangsaan Malaysia
}

\begin{abstract}
Students with disabilities pursuing higher education face special challenges. The research is intended to 1) identify the kinds of academic assessment, 2) analyze the implementation of the running curriculum, 3) elicite the instructional strategies upon the readiness for college admission. This study was a survey on school policy involving 39 high schools of special education in Central Java, Indonesia. Data was collected by means of questionnaire and interview of experience-based teaching aligned to the curriculum. The questionnaire was used get the data on the curriculum content and the employed instructional strategies. In addition, the interview was to get data on the impact of instructional strategy. The data from the questionnaire were analyzed descriptive quantitatively, while the qualitative data from the interview was used to crosscheck and support the resulted analysis of quantitative data. The results showed that 1) the academic assessment was highly individualized, 2) the curriculum and instruction were diversified on the basis of students' needs and capabilities, 3) the curriculum and instructional strategies give better impct of vocational skills rather than academic competence. The research reached the conclusion that individual and diversified curriculum and instruction impemented in special schools turn to be typical strategies in preparing the academic readiness for college admission.
\end{abstract}

Keywords: Post-school-transition, diversification, disability, college

\section{Introduction}

\section{The Significance of Post School Transition for Students with Disabilities (SWD).}

Post-school transition is an important period where a young person is able to access information and make choices after leaving school. However, individuals with disabilities have the lower enrollment to college than those without disabilities (Lightfoot, Janemi, \& Rudman, 2018) As it is generally acknowledged, students with disabilities (SWD) are the most vulnerable individuals in deciding the post-schooling option for their future. They face unique challenges and issues in their school years by which the post-school transition program is believed to be one factor that gives great impacts on the success in their employment or further education (Lawson \& Shields, 2014; Carter, Trainor, Cakiroglu, Swedeen, Owens, 2010). The importance of post-school transition is also mentioned by Kurth \& Mellard (2006) proving several SWDs comprised 9\% of the national population of students in the United States were enrolled in college (Cawthon \& Cole, 2010). Another research (Rizki, 2014) found that $17.85 \%$ of the population with disabilities in three different special school settings were interested in continuing to study in college. Unfortunately, this research does not mention the number of them accepted in college. However, the data of the preliminary research showed an increasing number of graduates 
interested in college admission in 2018. The research found 159 out of 651 graduates (24.2\%) chose to study further. This figure reveals that post-school transition program conducted in special schools has a tacit influence on the college option among the graduates upon leaving their schools. The curriculum is one of the main roles in the perspective of post-school transition.

Along the development of life-long learning, wide opportunity for students with disabilities to continue the study to university has been opened since the commencement of inclusive education in the last two decades regardless of the handicapping conditions the students may have. This group of minority may have somewhat limitation to achieve due to their internal and external barriers. Internal barriers such as visual, hearing as well as physical impairement may cause the diterioration of their self-concept that hinder them to learn equally in a college. Additionally, external problems such the lack of social interaction with the peer students and the lecturers. It is expected that peer students and lecturers establish a positive attitude towards students with disabilies (Murray, Flannery, \& Wren,2008). In another case, the unaccessible environment and the available learning accommodation of facilities are not effective for them to adjust (Cawthon \& Cole, 2010). These all may cause them to lag behind the peers in term of academic achievement.

The right of students with disabilities to get accessed to higher education was based on the grand theory of learning by Rogers (1982) with the belief that every human can learn irrespective to those with disabilities (Yusuf, S,. \& Nurikhsan, J., 2008). These are some principles of learning that should happen to students including those with disabilities. It is basically noted that learning could happen well to the learners when could they feel the significance for their life, freedom, and least threats while learning.

However, these all do not happen quite well for those with disabilities. Some students with disabilities often could feel the meaning of learning since their internal problems dominate the emotion. Their feeling of low selfesteem often makes them discouraged and lack of motivation. Moreover, those with moderate and severe handicapping conditions feel that learning is a burden rather than enjoyment. They feel the threats coming not only from their external dignity but also from the external aspects such as being neglected and bullying due their bizzare behavior. In a such condition, Rogers suggests specific teaching approach functioning as psychological therapy where the self-concept and motivation buildings are inculcated among the learners with disabilities (Corey, 2009). These priciples, unfortunately, are not fully implemented in special schools of the research sites. This research, therefore, was to see the effects of curriculum and the instructional strategies on the students in special schools particularly in the respect of academic compenetence which was prepared for college admission.

\section{Method}

The study was a survey as a mapping model of research. A total number of 39 special schools of high school level existed in Central-Java where the sample of this research taken through purposive sampling. The subjects of the research were of 78 respondents comprised from 39 headmasters and 39 senior teachers dealing with the implementation of the curriculum. The research was mixed method of validating quantitative data model (Creswell,2007). In this model, both quantitative and qualitative approaches of survey were employed to collect, analyze the data, and validate the results simultaneously. While the quantitative data were collected by means of questionnaire, in another way, the qualitative data were gathered through interview.

In this survey research, data on post-school transition program was collected employing questionnaire and interview. The questionnaire was addressed to the headmasters and teachers to collect the data on experiencebased teaching aligned to the curriculum content and the employed instructional strategies. Meanwhile, the interview was addressed to the students with disabilities in the special schools so as to get the information on the instructional impact. The questionnaire was a self-reported instrument which was constructed in four-scaled option by Likert. The instrument was measured through interrated to get the agreement from the experts in 
special education. The data from the questionnaire were analyzed descriptive quantitatively, while the qualitative data resulted from the interview was used to support the validity of the quantitative data.

\section{Results}

\section{Pre-course Assessment for New Students in High School Level of Special Schools}

The assessment is intended to get the information on the number of special schools conducting the diagnostic assessment in terms of academic and vocational potentials, and specific talent and interest. This assessment does not mean to screen the enrollment in the respective school. Instead, it is applied to see the tendency of the children during the school period of the learning process. Besides. The result is also useful to predict the final orientation of the skill development of career option upon leaving the schools. The result of the assessment can be seen in the following table.

Table 1. Pre-Course Assessment on the Students' Potentials to Career Option

\begin{tabular}{lll}
\hline Types of Assesment & Number of Special Schools & Percentage \\
\hline Akademic Potential & 13 & $33,3 \%$ \\
Vocational Potential & 22 & $56,4 \%$ \\
Dominant Talent \& & 4 & $10.3 \%$ \\
Interest & & \\
\hline
\end{tabular}

From Table 1, it shows 13 out of 39 special schools (33,3\%) carried out academic potentials, 22 schools (56, $4 \%)$. While the rest, 4 schools $(10,3 \%)$ carried out specific assessments on talent and interest. This means most of the special schools (56.4) put bigger attention to vocation for the students in the future.

\section{Curriculum Diversification}

To prepare the students for college education, special schools implement various curriculums. There are at least three types of the curriculum; a standardized curriculum from the Central Government, modified curriculum, and individualized curriculum. Below is the option of the curriculum that special schools use to prepare the students either for pursuant study or vocational choice. Each of the curricula contains the package of learning materials, which is proportionally balanced between the academic and vocational loads of skills. Below is the data of the curriculum implementation in special schools.

Table 2. The Curriculum Implemented in Special Schools Prepared for College Education

\begin{tabular}{lll}
\hline Types of Curriculum & Number of Special Schools & Percentage \\
\hline National Curriculum & 20 & $51 \%$ \\
Modified Curriculum & 16 & $41 \%$ \\
Individualized & 3 & $8 \%$ \\
Curriculum & & \\
\hline
\end{tabular}

Based on Table 2, The data shows 20 out of 39 special schools (51\%) implement the given curriculum, 16 special schools (41\%) make use of modified curriculum, and the rest three special schools (8\%) apply the individualized curriculum in addition to the modified curriculum. It means, most of the special schools use given curriculum as the main reference. Modified curriculum with a bigger portion of vocational load may be 
necessary for students with lower cognitive function. Individualized curriculum, additionally, is given to those with dominantly high or low achievement.

\section{Instructional Strategies Implemented in Special Schools.}

There are three modes of instruction typically implemented in special schools. They are a classical, cluster, and individual modes of teaching strategy. Classical instruction is used in a class with the similarly high function of intellectual capacity. While the cluster is implemented for a small group of students with lower function, individual instruction is given for one or two students who badly need specific self-help in daily life.

Table 3. Modes of Instruction Typically Implemented in Special Schools.

\begin{tabular}{lll}
\hline Types of Instruction & Number of Special Schools & Percentage \\
\hline Classical Instruction & 20 & $51 \%$ \\
Cluster Instruction & 17 & $44 \%$ \\
$\begin{array}{l}\text { Indivdualized } \\
\text { Instruction }\end{array}$ & 2 & $5 \%$ \\
\hline
\end{tabular}

Table 3 shows 20 out of 39 special schools or (51\%) use a classical mode of instruction, 17 out of 39 special schools (44\%) use modified instruction through cluster model for a small group with specific learning problems. For a few students with severe problems, individualized instruction may fit them better. Two out of 39 special schools $(5 \%)$ may have students with severe problems, so that individualized instruction may fit them better.

\section{Discussion}

\section{The role of the school curriculum in removing the barriers to college readiness}

The curriculum is designed and applied for a certain group of learners with the relatively average standard of capabilities to achieve the objectives of the education (Ornstein \& Hunkins, 2013). Those with under standard capability may need a modified curriculum, and modified curriculum needs differentiated instructional strategies correspondingly (Gibson, \& Hasbrouck, 2008). In their book, Gregory and Chapman (2007) also note the importance of diversification when the curriculum is used in groups of heterogeneous learners. "One size does not fit all" implies that it is essentially crucial to diversify the curriculum to correspond to the group of diverse students.

It is important to acknowledge that the curriculum for the special schools in Indonesia is constructed and reconstructed under the reference of the national curriculum. It is firstly designed and is standardized by the National Board of Education Standardization under the Ministry of Education. To plan a post-school transition program, therefore, the curriculum in special schools requires diversification. Furthermore, to adjust the curriculum to college enrollment purposes, diversification is made in such a way through the following aspects; students' academic potential assessment, content and material adjustment, differentiated delivery system, and multi-modal assessment of learning outcome.

\section{Pre-course assessment}

The purpose of the assessment is to get the information on the students potential and interest. In addition type of assessment is functioning as a diagnostic instrument for the academic potential elicitations (Pierangelo \& Giuliani, 2008). It does not mean, at all, to screen the enrollment to the respective school. Instead, it is applied to see the tendency of the children during the school period of the learning process. This assessment also functions 
to predict the final orientation of skill development of career option upon leaving the schools. Since the coming new students to the special school are all those suspected to have disabilities with various degree of handicapping condition, Pennington (2009) suggests differential diagnostic assessment be used to avoid mislabeling and inappropriate treatment accordingly. However, instead of assessing the child' weaknesses, positive potentials are highlighted. Therefore, it is important to consider the use of differential assessment in accordance with the Individualized Educational Program (IEP) which is prepared by involving related agents in an interdisciplinary team. A meticulous and authentic assessment resulted from the interdisciplinary team would undoubtedly become the capital source of curriculum and instructional programs for the respective children.

\section{Curriculum \& instruction Diversification}

To prepare the students for college education, special schools implement the various curriculum. There are at least three types of the curriculum; a standardized curriculum which is given from Central Government, modified curriculum, and individualized curriculum. To prepare the students particularly for pursuant study, it is crucial to consider the proportion between academic and vocational loads of skills. Instead of 30\% academic: $70 \%$ vocational loads, now that the focus is on academic purpose. Henceforth, the portion of academic intention is reversed to $70 \%$. Or else, additional time of learning materials on college test should be well considered (Gregory, \& Chapman, 2007). In comparison to the curriculum in inclusive schools where the academic load is paramount, the curriculum for the special schools is more settled in a way that the structure of the content is set up for a somehow less heterogeneous class in term of the students' characteristics. Unlike an inclusive school where many diverse students are mainstreamed, a class in special schools is a self-contained base in which the class contains students with similar handicapping conditions. A self-contained class for visual impairment, for instance, is only contained students with visual problems with somewhat degree of visual equity differences. In the context of curriculum diversification, modification is emphasized more on the group rather than the individual basis of response to intervention (RTI), though the instruction mode can also be ( Ormrod, 2011; Woolfolk, 2013). Furthermore, when diversification is made on the individual needs, it is believed the curriculum would be much more fruitful regardless of the time consumed.

In addition, the instructional mode aligned to the diversified curriculum is another important point as the subsequent consideration. There are three modes of instruction typically implemented in special schools. They are a classical, cluster, and individual modes of teaching strategy. Classical instruction is used in a class with the similarly high function of intellectual capacity. While the cluster is implemented for a small group of students with lower function, individual instruction is given for one or two students who badly need specific self-help in the activity of daily living. Two kinds of instructional modes, cluster and Individualized Educational Program (IEP), serve as the typical instructional strategies in classrooms of children with disabilities. So far, the employment of these instructional modes remain the most favourable choice among teachers in classrooms with diversities (Salim, Gunarhadi, \& Anwar, 2015). The impact of the diversified curriculum into differentiated instructional modes was also expressed in the following statement "Cluster model and individual educational programs fit better for students with lower cognitive function. Students can learn better in a smaller group rather than learning in a big classical setting" said SKM, a senior teacher.

\section{Conclusion}

From the above discussion, the research draws the following conclusions:

Students graduating from special schools face various barriers to a college education due to internal and external problems. Most of the special schools conductthe prescriptive assesment to identify the academic potentials

For the post-transition program to be effective, curriculum and instruction in special schools are diversified so as to adjust to the students' needs and capabilities. 
The diversified curriculum and instruction is typically implemented on the basis of individual and cluster mode of instruction.

Since not all special schools in the research site conduct similar strategy, the research recommends more specific strategies that fit better such as extra courses and guidance for students to get ready to college admission

\section{Acknowledgment}

Special thank is extended to the Ministry of Research, Technology \& Higher Education, Indonesia for funding this research.

\section{References}

Carter, E,. Trainor, A,. Cakiroglu, O., Swedeen, B., \& Owens, L. (2010). Availability of and access to career development activities for transition-age youth with disabilities. Career Development for Exceptional Individuals 33, (1), 13-24.

Creswell, J., W. \& Clark, V., L. (2007). Designing and conducting mixed methods research. Thousand Oaks, London, New Delhi: Sage Publication

Cobb, B., \& Alwell, M. (2009). Transition planning/coordinating interventions for youth with disabilities: A systematic review. Career Development for Exceptional Individuals, 32 (2),70-81.

Corey, G. (2009). Theory and Practice of Counseling \& psychotherapy. Bandung: Reflika Aditama

Directorate of Special Education, (2013). Basic competence: Model of life skill syllabus for high special schools. Jakarta: High School Directorate, Ministry of Education \& Culture.

Gibson, V., \& Hasbrouck, J. H. (2008). Differentiated instruction: Grouping for success. New York: McGrawHill Companies, Inc.

Gregory, G.H., \& Chapman, C. (2007). Different instructional strategies: One size does not fit all. Thousand Oaks, California: A Sage Publication Company.

Kurth, N., \& Mellard, D. (2006). Students perceptions of the accommodation process in postsecondary education. The Journal of Postsecondary Education and Disability, 19 (1), 71-84.

Lawson, J. \& Shields, M. (2014). Post-school transition-preparation for high school students with disabilities: A vital issue for special education. Teach Journal of Christian Education, 8, (1), 52-56

Lightfoot, A., Janemi, R., \& Rudman, D, L. (2018). Perspectives of North American postsecondary students with learning disabilities: A scoping review. Journal of Postsecondary Education and Disabilities, 31(1), 57-74.

Murray, C., Flannery, B., \& Wren, C. (2008). University staff members'attitude and knowledge about learning disabilities and disabilities support services. The Journal of Postsecondary Education and Disablity, 21 (2),73-90

Ormrod, J. E. (2011). Educational psychology: Developing learners. Boston, MA: Pearson Education, Inc.

Ornstein, A.C., \& Hunkins, F.P., (2013). Curriculum: Foundation, Principles, and Issues. New Jersey: Pearson Education Inc.

Pennington, B, F. (2009). Diagnosing learning disorder: A neuropsychological framework. Spring Street, New York: Guilford Publication, Inc.

Pierangelo, R. \& Giuliani, G. (2008). Understanding assessment in the special education process. Thousand Oaks, CA: Sage Asia-Pacific Pte. Ltd.

Rizki, U. F. (2014). Need identification of post-school transition for students with disabilities. Indonesian Journal of Disability Studies, 1,(1),52-59

Salim, Gunarhadi, \& Anwar. (2015). Differentiated instruction for children with special needs in inclusive schools. Surakarta: UPT UNS Press.

Yusuf, S,. \& Nurikhsan, J. (2008). Theory of personality. Bandung: PT. Remaja Rosdakarya 